International Journal of Agriculture, Environment and Bioresearch

Vol. 06, No. 06; 2021

ISSN: $2456-8643$

\title{
ASSESSMENT OF F1 PROGENIES OF SWEETPOTATO (Ipomoea batatas (L.) Lam) FOR YIELD AND SUSCEPTIBILITY TO SWEETPOTATO WEEVIL (Cylas puncticollis) UNDER RAINFED CONDITION IN UMUDIKE, NIGERIA
}

\author{
ULASI, J. I. and RIVERS, E. U. \\ Department of Crop Science, Faculty of Agriculture, University of Uyo, P.M.B 1017, Uyo, Akwa, Ibom State.
}

https://doi.org/10.35410/IJAEB.2021.5685

\begin{abstract}
Poor storage root yield and incidence of sweetpotato weevil Cylas puncticollis constitute major constraints to sweetpotato production in Nigeria. The objective of this study was to assess newly developed progenies of sweetpotato and identify promising genotypes with high storage root yield and resistance to Cylas spp. For this purpose, a field experiment was conducted at the National Root Crops Research Institute, Umudike, Southeast Nigeria during the 2015 and 2016 cropping seasons to evaluate diversity across progenies of different sweetpotato families, namely: SautiX442162 (6), SautiXLigri (5) and Sauti Poly Cross (10), including two national check varieties (Umuspo 3 and TIS 87/0087). This experiment was laid out in a randomized complete block design with three replicates. In this study, progenies of sweetpotato exhibited morphological variability storage root characters. SautiXLigri/4 (13.33t/ha) and SautiX442162/1 (12.70 t/ha) produced higher fresh storage root yield than the national check (Umuspo3) while five genotypes; SautiXLigri/4 (13.33t/ha), SautiX442162/1 (12.70 t/ha), SautiX442162/5 (12.03 t/ha), SautiX442162/2 (11.04t/ha) and Sauti PC/9 (9.97t/ha) produced higher fresh storage root yield than the national check (TIS 87/0087). Among the twenty one genotypes evaluated, nine genotypes; SautiX442162/5, SautiX442162/3, SautiX442162/2, SautiXLigri/2, Sauti PC/4, Sauti x 442162/1, Sauti PC/1, Sauti PC/5, Sauti x 442162/6 were susceptible to the attack of C. puncticollis. Sautix442162/5 had the highest attack of C. puncticollis, followed by Sautix442162/3 and Sautix442162/2 while twelve genotypes; Sauti PC/2, Sauti PC/3, Sauti PC/6, Sauti PC/7, Sauti PC/8, Sauti PC/9, Sauti PC/10, SautiX442162/4, SautiXLigri/1, SautiXLigri/3, SautiXLigri/4, SautiXLigri/5 did not record attack of C. puncticollis. This suggests that these genotypes may possess resistance genes and could be incorporated in breeding programs to produce hybrid varieties that are high yielding and resistance to Cylas puncticollis.
\end{abstract}

Keywords: Cylas puncticollis, Diversity, Progeny, Resistance, Storage root, Sweetpotato.

\section{INTRODUCTION}

Sweetpotato (Ipomoea batatas [L.] Lam.) is a stable root crop cultivated the different continents of the world on approximately 8.21 million hectare (ha) with an estimated annual yield of 104.02 million tonnes (FAOSTAT, 2014). Across many tropical countries, sweetpotato is regarded as the second important root crop after cassava (FAOSTAT, 2006). Sweetpotato is commonly cultivated in Africa, Asia, Latin America, with China accounting for 52\% of the crop grown on approximately 4.7 million hectares (FAOSTAT, 2009). Africa produces only about $6 \%$ of the 
Vol. 06, No. 06; 2021

ISSN: $2456-8643$

world crop and it is mainly utilized as food for human consumption, hence the crop has a relatively large nutritional impact (Gibson and Aritua 2002). In the tropics, the average yield potential of sweetpotato ranges from $20-50 \mathrm{t} / \mathrm{ha}$. It is the third most important tuberous root crop (Gibson and Aritua, 2002) with annual world production of about 131 million tons, on approximately 9 million hectares with mean estimated yields of $13.7 \mathrm{t} / \mathrm{ha}$. In Nigeria, however, farmers have recorded one of the world's lowest average sweetpotato yield of $3 \mathrm{t} / \mathrm{ha}$ (FAO, 2015).

Across the African continent, sweetpotato is consumed as a staple food crop and has gained massive production on approximately 2.1 million ha and with an average yield of 9.9 million tonnes fresh storage roots annually (Anyanga et al., 2013). The storage roots can be processed into various forms such as fried chips, boiled roots or as flour for confectionary purposes, thereby enhancing its value chain (Engoru et al., 2005). In some parts of Nigeria, the young leaves of the crop are consumed as leafy vegetable as part local diet and its roots serves as a rich source of carbohydrate (Mwanga et al., 2007; Burri, 2011). China stands out as the highest in terms of sweetpotato production across the globe while Nigeria accounts for the highest production of sweetpotato in the African continent. (FAOSTAT, 2014). Majority of sweetpotato farmers in Nigeria are small holder farmers, whose preference for the crop is largely due to its short gestation period of about four to five months, depending on the variety and it ability to survive on different ecology types (Antiaonong and Bassey, 2008). Sweetpotato is considered a low-input crop by most rural farmers owing to its high productivity per unit area, early maturity, tolerance to water stress and comparatively good performance in soils with minimal fertility status (Kapinga et al., 1995). Sweetpotato production in Nigeria suffers numerous constraints including biotic, abiotic, unavailability of improved varieties, which have contributed to the existing low yields of 3t/ha compared to the potential productivity of the crop varying from 15 to 23 t ha-1 (Sebastiani et al., 2007). Amongst these constraints, sweetpotato weevil infestation caused by Cylas puncticollis constitute a major setback to sweetpotato production in Nigeria. To control the sweetpotato weevils, good agronomic practices such as proper field sanitation, early planting and early harvesting, as well as application of agro-chemical as control measures have been implemented by farmers. There are however, environmental and health hazards associated with the use of agro-chemical constitute a limiting factor coupled with the fact that it has minimal effects on the juvenile weevils that develop in roots and vines (Lebot and Bradshaw, 2010). For most farmers, early sowing is not a common cultural practice because of the inadequate planting materials at the inception of rainy season. Small holder farmers in the Tropics are averse to early harvesting of sweetpotato because continuous and gradual harvest to minimize post-harvest losses. In many African countries, lack of modern storage facilities, postharvest handling facilities during packaging and transport, lack of technical-know-how on processing and value addition as well conveying bulky produce on poor roads are factors that undermine the production sweetpotato (Masumba et al., 2005). Consequently, fresh storage roots of sweetpotato are vulnerable to several pests and diseases. Predominately, sweetpotato weevils (Cylas puncticollis) are reported to be a main insect pests damaging the fresh storage roots of sweetpotato in the field. Sweetpotato weevil species were reported to have inflicted severe damage every harvestable part of the plant with yield losses up to 80\% (Smit et al., 2001; Rees et 
Vol. 06, No. 06; 2021

ISSN: $2456-8643$

al., 2003). Infestation by sweetpotato weevil to sweetpotato storage causes both severe injury to the storage roots as well as quantitative loss. It is also capable of causing depreciation in terms of quality and loss of market value because of the unpalatable terpenoids produced by the plant in response to infestation caused by the weevil (Stathers et al., 2003). End users therefore could either reject or pay reduced prices for damaged roots (Ndunguru et al., 1998). The larvae stage of the sweetpotato weevil is the damaging stages as the adults prefer to feed on the tuber, causing widespread damage in the field and in storage. Sweetpotato weevil is regarded as a one of the post-harvest insect that reduces both economic and nutritional value of the root during storage and can reduce its shelf life. The major damage of the pest is the mining of the tubers by larvae (Stathers et al., 1999).

Breeding sweetpotato varieties with long-lasting resistance to weevils is encouraged as the best measure to control weevils (Muyinza et al., 2012; Anyanga et al., 2013). However, weevil resistance varieties are yet to be developed and released in Nigeria. It is thus important to identify weevil resistant germplasm through effective screening involving adequate weevil infestation among newly developed progenies of sweetpotato from hybridization across different locations with high incidence and severity of Cylas puncticollis (Stathers et al., 2003). Evaluation of newly developed progeny in yield trial could reveal some promising genotypes with high root yields and other resistance to Cylas puncticollis in Nigeria. The aim of this study was to evaluate twenty one sweetpotato progenies for storage root yield and resistance to Cylas puncticollis

\section{MATERIALS AND METHOD}

Study Site: The experiment was carried out during the 2015 and 2016 planting seasons at the National Root Crops Research Institute, Umudike, Southeast Nigeria. Umudike is located at latitude $05^{\circ} 29^{\prime} \mathrm{N}$, longitude $07^{\circ} 33^{\prime} \mathrm{E}$, altitude $122 \mathrm{~m}$ above sea level. Umudike is located in the humid tropics and has a total rainfall of around 2,177 $\mathrm{mm}$ per year, an average annual temperature of around $26^{\circ} \mathrm{C}$ and its soil is classified as sandy-loamy Utisol (NRCRI, 2012).

Nursery Management: The nursery soil consisted of a mixture of topsoil, organic material and river sand in a ratio of 3:2:1. The nursery was prepared in the greenhouse of the National Root Crops Research Institute, Umudike and Southeast, Nigeria using polyethylene bags containing 1 $\mathrm{kg}$ of soil. After the seeds were soaked in cold water for about twenty-four hours to break the dormancy, some of the seeds that germinated and were carefully isolated from the container with cold water and sown separately in the well-watered soil in polyethylene bags.

Agronomic practices: The land for the trial site was cleared, ploughed, harrowed and skinned. The prepared land was demarcated in plots of $1.5 \mathrm{~m} 2(1 \mathrm{mx} 1.5 \mathrm{~m})$. The field was laid out in an extended three replicate design and two control varieties were planted at intervals. The planting distance was $1 \mathrm{mx} 0.3 \mathrm{~m}$. This resulted in five stands of sweetpotato per plot, equivalent to 33,333 stands per hectare. Therefore, the land area for this investigation was $240 \mathrm{~m}^{2}$. Planting was done on July 21, 2015 and April 18, 2016 with five vines on each plot. The plants were fed with rain. Weeding was done 6 and 12 weeks after planting (WAP). Compound fertilizer (NPK 15:15:15) was applied at a rate of $400 \mathrm{~kg} / \mathrm{ha} 4 \mathrm{WAP}$ with side placement. Records were made at $16 \mathrm{WAP}$ 
(Ezulike et al., 2001) about the number of roots per plot, sellable (> $100 \mathrm{~g}$ ) and unsalable roots (<100 g) (Levett, 1993), severity of damage by Cylas puncticollis (Stathers et al., 2003).

Table 1: Progenies of Sweetpotato and their sources

\begin{tabular}{|rlll|}
\hline S/No. & Parents & Cross type & Source \\
\hline 1. & Sauti $x$ 442162/1 & Controlled Cross & CIP, Kumasa, Ghana \\
2. & Sauti x 442162/2 & Controlled Cross & CIP, Kumasa, Ghana \\
3. & Sauti x 442162/3 & Controlled Cross & CIP, Kumasa, Ghana \\
4. & Sauti x 442162/4 & Controlled Cross & CIP, Kumasa, Ghana \\
5. & Sauti x 442162/5 & Controlled Cross & CIP, Kumasa, Ghana \\
6. & Sauti x 442162/6 & Controlled Cross & CIP, Kumasa, Ghana \\
7. & Sauti x Ligri/1 & Controlled Cross & CIP, Kumasa, Ghana \\
8. & Sauti x Ligri/2 & Controlled Cross & CIP, Kumasa, Ghana \\
9. & Sauti x Ligri/3 & Controlled Cross & CIP, Kumasa, Ghana \\
10. & Sauti x Ligri/4 & Controlled Cross & CIP, Kumasa, Ghana \\
11. & Sauti x Ligri/5 & Controlled Cross & CIP, Kumasa, Ghana \\
12. & Sauti PC/1 & Poly Cross & CIP, Kumasa, Ghana \\
13. & Sauti PC/2 & Poly Cross & CIP, Kumasa, Ghana \\
14. & Sauti PC/3 & Poly Cross & CIP, Kumasa, Ghana \\
15. & Sauti PC/4 & Poly Cross & CIP, Kumasa, Ghana \\
16. & Sauti PC/5 & Poly Cross & CIP, Kumasa, Ghana \\
17. & Sauti PC/6 & Poly Cross & CIP, Kumasa, Ghana \\
18. & Sauti PC/7 & Poly Cross & CIP, Kumasa, Ghana \\
19. & Sauti PC/8 & Poly Cross & CIP, Kumasa, Ghana \\
20. & Sauti PC/9 & Poly Cross & CIP, Kumasa, Ghana \\
21. & Sauti PC/10 & Poly Cross & CIP, Kumasa, Ghana \\
22. & Umuspo 3 & Check Variety & NRCRI, Umudike, Nigeria \\
23. & TIS87/0087 & Check Variety & NRCRI, Umudike, Nigeria \\
\hline
\end{tabular}

The sweetpotato accessions were harvested plot by plot and the number of tubers infected by C. puncticollis were counted and their percentages determined as:

Then, the severity of damage was indicated for each accession using a five point (1-5), where: $1=0 \%: \quad$ no observable damage of sweetpotato tubers by weevils (C. puncticollis) $2=1 \%-25 \%$ sweetpotato root tubers attacked by $C$. puncticollis indicating very little damage. $3=26 \%-50 \%$ sweetpotato root tubers attacked by $C$. puncticollis indicating moderate damage. $4=51 \%-75 \%$ sweetpotato root tubers attacked by $C$. puncticollis indicating extensive damage. $5=76 \%-100 \%$ sweetpotato root tubers attacked by $C$. puncticollis indicating severe damage.

Data Analysis: Harvest data were subjected to Analysis of variance (ANOVA) and mean separation was carried out using the Least Significant Difference (LSD) test at 5\% level of 
Vol. 06, No. 06; 2021

ISSN: $2456-8643$

significance. Pearson's correlation analysis was done to show association among yield and yield related components of sweetpotato genotypes. Principal component analysis was done for the yield related traits.

\section{RESULTS}

The results presented in Table 2 showed that in 2015 cropping season, the analysis of variance revealed there was no significant $(\mathrm{P} \leq 0.05)$ differences among genotypes for unmarketable root number, marketable root number and unmarketable root weight but there was significant difference among the genotypes for marketable root weight and yield. (Table 2). In 2016 cropping season, analysis of variance showed that there was no significant $(\mathrm{P} \leq 0.05)$ differences among genotypes for unmarketable root number, marketable root number, unmarketable root weight yield but there was significant difference among the genotypes for marketable root weight (Table 2). In 2015 cropping season, Umuspo3 recorded the highest mean of marketable root weight $(1.90 \mathrm{~kg} / \mathrm{ha})$ while SautiXLigri/4 produced the highest fresh storage root yield in 2015 cropping season (13.33t//ha). The fresh storage root yield of both check varieties Umuspo 3 and TIS 87/0087 were 8.66t/ha and 7.86t/ha, respectively (Table 4). In 2016 cropping season, LigriXFaara/4 recorded the highest mean of marketable root weight $(1.25 \mathrm{~kg} / \mathrm{ha})$ and highest fresh storage root yield (9.00t//ha.) In 2015 cropping season, the fresh storage root yield of both check varieties Umuspo 3 and TIS 87/0087 were 12.60t/ha and 8.67t/ha, respectively (Table 2). Table 2 showed that in 2015 cropping season, two genotypes; Sauti x Ligri/4 (13.33t/ha) and SautiX442162/1 (12.70 t/ha) produced higher fresh storage root yield than the national check (Umuspo3) while five genotypes; Sauti x Ligri/4 (13.33t/ha), SautiX442162/1 (12.70 t/ha), SautiX442162/5 (12.03 t/ha), SautiX442162/2 (11.04t/ha) and Sauti PC/9 (9.97t/ha) produced higher fresh storage root yield than the national check (TIS 87/0087). In 2016 cropping season, only SautiXLigri/5 (6.73 t/ha) produced higher fresh storage root yield than the national check varieties. The storage root yield of both years showed that the genotypes produced higher yield in 2015 cropping season than in 2016 cropping season. This could be attributed to the effect of early planting and decline in rainfall during the vegetative stage of the crop.

The result as presented in Table 2 indicated the analysis of variance revealed that there was no significant $(\mathrm{P} \leq 0.05)$ differences among genotypes for Cylas incidence and Cylas severity. Among the twenty one genotypes evaluated, nine genotypes; SautiX442162/5, SautiX442162/3, SautiX442162/2, SautiXLigri/2, Sauti PC/4, SautiX442162/1, Sauti PC/1, Sauti PC/5, SautiX $442162 / 6$ were susceptible to the attack of $C$. puncticollis. SautiX442162/5 had the highest attack of $C$. puncticollis, followed by SautiX442162/3 and SautiX442162/2 while twelve genotypes; Sauti PC/2, Sauti PC/3, Sauti PC/6, Sauti PC/7, Sauti PC/8, Sauti PC/9, Sauti PC/10, SautiX 442162/4, SautiXLigri/1, SautiXLigri/3, SautiXLigri/4, SautiXLigri/5 did not record attack of $C$. puncticollis may possess resistance genes 
Vol. 06, No. 06; 2021

ISSN: $2456-8643$

Table 2: Means of 21 genotypes for total storage root yield for 2015 and 2016 planting seasons

\begin{tabular}{|c|c|c|c|c|c|c|c|c|c|c|c|c|}
\hline Genotypes & $\begin{array}{c}\text { MR } \\
\text { N } \\
2015\end{array}$ & $\begin{array}{c}\text { UM } \\
\mathbf{N} \\
2015\end{array}$ & $\begin{array}{c}\text { MR } \\
\text { N } \\
2016\end{array}$ & $\begin{array}{c}\text { UR } \\
\text { N } \\
201 \\
6\end{array}$ & $\begin{array}{c}\text { MRW } \\
2015 \\
(\mathrm{Kg} / \mathrm{h} \\
\text { a) }\end{array}$ & $\begin{array}{c}\text { URW } \\
2015 \\
(\mathrm{Kg} / \mathrm{h} \\
\text { a) }\end{array}$ & $\begin{array}{c}\text { MRW } \\
2016 \\
(\mathrm{Kg} / \mathrm{h} \\
\text { a) }\end{array}$ & $\begin{array}{c}\text { URW } \\
2016 \\
\text { (Kg/h } \\
\text { a) }\end{array}$ & $\begin{array}{c}\text { Yiel } \\
\text { d } \\
2015 \\
(t / h a \\
)\end{array}$ & $\begin{array}{c}\text { Yiel } \\
\text { d } \\
2016 \\
(t / h a \\
) \\
\end{array}$ & $\begin{array}{c}\text { Cylas } \\
\text { inciden } \\
\text { ce }\end{array}$ & $\begin{array}{c}\text { Cylas } \\
\text { severit } \\
\mathbf{y}\end{array}$ \\
\hline $\begin{array}{l}\text { Sauti } x \\
\text { Ligri/5 }\end{array}$ & 3.00 & 2.50 & 2.50 & 3.00 & 1.00 & 0.10 & 1.00 & 0.10 & 6.73 & 6.73 & 0.00 & 0.00 \\
\hline $\begin{array}{l}\text { Sauti x } \\
442162 / 5\end{array}$ & 6.00 & 1.00 & 3.00 & 3.00 & 1.80 & 0.05 & 0.50 & 0.05 & $\begin{array}{c}12.0 \\
3\end{array}$ & 5.93 & 2.00 & 2.50 \\
\hline $\begin{array}{l}\text { Sauti } x \\
\text { Ligri/2 }\end{array}$ & 4.00 & 0.00 & 3.00 & 3.00 & 1.18 & 0.00 & 0.80 & 0.09 & 7.80 & 5.93 & 1.00 & 1.00 \\
\hline Sauti PC/8 & 2.00 & 0.50 & 2.50 & 2.50 & 0.65 & 0.04 & 0.73 & 0.04 & 3.73 & 5.23 & 0.00 & 0.00 \\
\hline Sauti PC/4 & 1.50 & 1.50 & 5.00 & 3.00 & 0.55 & 0.11 & 0.70 & 0.07 & 1.72 & 5.13 & 1.00 & 1.50 \\
\hline Sauti PC/9 & 3.50 & 1.00 & 1.50 & 2.50 & 1.33 & 0.05 & 0.75 & 0.05 & 9.97 & 5.13 & 0.00 & 0.00 \\
\hline $\begin{array}{l}\text { Sauti x } \\
442162 / 4\end{array}$ & 2.00 & 1.00 & 2.50 & 2.00 & 0.50 & 0.03 & 0.80 & 0.09 & 3.50 & 5.13 & 0.00 & 0.00 \\
\hline $\begin{array}{l}\text { Sauti } x \\
\text { Ligri/1 }\end{array}$ & 3.50 & 3.00 & 5.00 & 3.00 & 1.15 & 0.15 & 0.70 & 0.07 & 8.07 & 5.13 & 0.00 & 0.00 \\
\hline Sauti PC/1 & 2.00 & 1.50 & 2.00 & 2.50 & 0.63 & 0.05 & 0.65 & 0.05 & 4.16 & 4.67 & 0.50 & 0.50 \\
\hline Sauti PC/7 & 3.00 & 2.00 & 3.50 & 2.00 & 0.70 & 0.10 & 0.55 & 0.15 & 5.97 & 4.46 & 0.00 & 0.00 \\
\hline Sauti PC/3 & 2.50 & 1.00 & 3.00 & 2.00 & 1.00 & 0.15 & 0.55 & 0.09 & 5.10 & 4.26 & 0.00 & 0.00 \\
\hline $\begin{array}{l}\text { Sauti x } \\
442162 / 3\end{array}$ & 2.50 & 1.50 & 4.00 & 3.00 & 0.60 & 0.13 & 0.55 & 0.07 & 4.83 & 4.26 & 1.50 & 1.50 \\
\hline $\begin{array}{l}\text { Sauti } \\
\text { PC/10 }\end{array}$ & 3.00 & 4.50 & 4.00 & 2.00 & 0.85 & 0.20 & 0.50 & 0.13 & 5.87 & 4.13 & 0.00 & 0.00 \\
\hline Sauti PC/5 & 3.00 & 1.50 & 3.50 & 2.00 & 0.85 & 0.05 & 0.50 & 0.10 & 5.13 & 3.97 & 0.50 & 1.00 \\
\hline $\begin{array}{l}\text { Sauti } x \\
\text { Ligri/3 }\end{array}$ & 2.00 & 1.00 & 1.00 & 2.00 & 0.50 & 0.08 & 0.50 & 0.08 & 6.36 & 3.86 & 0.00 & 0.00 \\
\hline $\begin{array}{l}\text { Sauti } x \\
\text { Ligri/4 }\end{array}$ & 3.50 & 3.00 & 3.00 & 1.50 & 1.25 & 0.15 & 0.45 & 0.13 & $\begin{array}{c}13.3 \\
3\end{array}$ & 3.83 & 0.00 & 0.00 \\
\hline Sauti PC/6 & 2.50 & 0.50 & 2.50 & 2.00 & 0.88 & 0.05 & 0.53 & 0.05 & 6.57 & 3.82 & 0.00 & 0.00 \\
\hline Sauti PC/2 & 1.00 & 3.00 & 5.00 & 2.00 & 0.25 & 0.15 & 0.40 & 0.10 & 2.90 & 3.30 & 0.00 & 0.00 \\
\hline $\begin{array}{l}\text { Sauti x } \\
442162 / 2\end{array}$ & 3.50 & 4.50 & 4.00 & 2.50 & 1.60 & 0.20 & 0.51 & 0.09 & $\begin{array}{c}11.4 \\
0\end{array}$ & 3.30 & 1.50 & 1.50 \\
\hline $\begin{array}{l}\text { Sauti x } \\
442162 / 1\end{array}$ & 4.50 & 2.00 & 4.50 & 2.00 & 1.85 & 0.10 & 0.40 & 0.10 & $\begin{array}{c}12.7 \\
0\end{array}$ & 2.00 & 1.00 & 1.00 \\
\hline $\begin{array}{l}\text { Sauti x } \\
442162 / 6\end{array}$ & 2.00 & 2.50 & 2.50 & 2.00 & 0.15 & 0.06 & 0.10 & 0.01 & 3.50 & 2.00 & 0.50 & 1.00 \\
\hline $\begin{array}{l}\text { TIS } \\
87 / 0087\end{array}$ & 4.00 & 1.50 & 5.00 & 3.00 & 1.30 & 0.00 & 0.90 & 0.07 & 8.67 & 6.57 & 0.00 & 0.00 \\
\hline Umuspo 3 & 4.00 & 3.00 & 3.00 & 2.00 & 1.90 & 0.00 & 0.85 & 0.09 & 12.6 & 6.16 & 0.00 & 0.00 \\
\hline
\end{tabular}




\section{International Journal of Agriculture, Environment and Bioresearch}

Vol. 06, No. 06; 2021

ISSN: $2456-8643$

\begin{tabular}{|lcccccccccccc|}
\hline Total & 2.98 & 1.89 & 3.28 & 2.37 & 0.98 & 0.09 & 0.61 & 0.08 & 7.07 & 4.56 & 0.41 & 0.50 \\
$\operatorname{LSD}(\mathrm{P} \leq 0.0$ & NS & NS & NS & NS & 0.66 & NS & 0.25 & NS & 3.99 & NS & NS & NS \\
$5)$ & & & & & & & & & & & & \\
\hline
\end{tabular}

MRN = Marketable root number, URN $=$ Unmarketable root number, MRW $=$ Marketable root weight $(\mathrm{kg} / \mathrm{t}), \mathrm{URW}=$ Unmarketable root weight $(\mathrm{kg} / \mathrm{ha})$

Table 3 showed the Pearson correlation co-efficients $(\gamma)$ for the storage root parameters for twenty one genotypes. Total storage root yield had significant and positive correlation coefficient with number of marketable roots and marketable weight/ha but negative correlation coefficient with unmarketable storage roots weight (Table 3). Correlation coefficients for the 7 traits are presented in Table 3. Generally, all the traits except unmarketable storage root weight at harvest exhibited positive correlation with total roots weight (yield). Some of the traits also exhibited significant and positive association among themselves as well as significant and negative association. Yield at harvest had a positive association with unmarketable fresh storage root weight $(\mathrm{r}=0.10)$. Yield at harvest had a positive and significant $(\mathrm{P} \leq 0.01)$ with root of marketable root number $(\mathrm{r}=0.77)$ as well as marketable fresh storage roots weight $(\mathrm{r}=0.87)$ (Table 3). Cylas incidence had a positive association with fresh storage root yield $(\mathrm{r}=0.18)$ and Cylas incidence had a positive and significant $(\mathrm{P} \leq 0.01)$ association with Cylas incidence $(\mathrm{r}=0.95)$ (Table 3).

Table 3: Pearson correlation co-efficients $(\gamma)$ for the storage root parameters for the 21 genotypes of sweetpotato

\begin{tabular}{|lccccccc|}
\hline & MRN & URN & $\begin{array}{l}\text { MRW } \\
(\mathrm{kg} / \mathrm{ha})\end{array}$ & $\begin{array}{l}\text { URW } \\
(\mathrm{kg} / \mathrm{ha})\end{array}$ & $\begin{array}{l}\text { Yield } \\
(\mathrm{t} / \mathrm{ha})\end{array}$ & $\begin{array}{l}\text { Cylas } \\
\text { Incidence }\end{array}$ & $\begin{array}{l}\text { Clyas } \\
\text { Severity }\end{array}$ \\
\hline MRN & & & & & & & \\
URN & 0.027 & & & & & & \\
MRW (kg/ha) & $0.855^{* *}$ & 0.111 & & & & & \\
URW (kg/ha) & -0.050 & $0.738^{* * *}$ & 0.010 & & & & \\
Yield (t/ha) & $0.777^{* *}$ & 0.203 & $0.875^{* *}$ & 0.104 & & & \\
Cylas Incidence & 0.202 & 0.051 & 0.244 & 0.058 & 0.181 & \\
Cylas Severity & 0.158 & 0.093 & 0.186 & 0.091 & 0.092 & $0.958^{* *}$ & \\
\hline **. Correlation is significant at the 0.01 level (2-tailed). & & & & \\
\hline
\end{tabular}

MRN = Marketable root number, URN = Unmarketable root number, MRW = Marketable root weight, URW = Unmarketable root weight

Three principal component axes (PC1 PC2 and PC3) were obtained in the principal component analysis (PC analysis had eigen values up to 1.0, presenting cumulative variance of $91.41 \%$ 
(Table 4). Principal component one (PC1), with eigen value of 2.92 , contributed $41.72 \%$ of the total variability. $\mathrm{PC} 2$, with eigen value of 1.79 , accounted for $25.68 \%$ of total variability while PC3, with eigen value of 1.67 , accounted for $23.99 \%$ of total variability observed among the twenty one sweetpotato genotypes, In PC1, the traits that accounted for most of the $41.72 \%$ observed variability among the twenty one genotypes included number of marketable roots, with vector loading of 0.850 , unmarketable storage root number (0.259), weight of marketable roots (0.905), weight of unmarketable roots (0.169), yield (0.867), Cylas incidence and Cylas severity (0.542 and 0.489 , respectively) (Table 4$)$.

Table 4: Principal component analysis of the 21 sweetpotato genotypes

\begin{tabular}{|lrrr|}
\hline & \multicolumn{3}{c|}{ Component } \\
& PCA 1 & PCA 2 & PCA 3 \\
\hline Marketable Root No. & 0.850 & -0.386 & 0.008 \\
Unmarketable Root No. & 0.259 & 0.512 & 0.737 \\
Marketable weight (kg/ha) & 0.905 & -0.331 & 0.065 \\
Unmarketable weight (kg/ha) & 0.169 & 0.575 & 0.715 \\
Yield (t/ha) & 0.867 & -0.314 & 0.205 \\
Cylas Incidence & 0.542 & 0.621 & -0.547 \\
Cylas Severity & 0.489 & 0.681 & -0.528 \\
Total & 2.922 & 1.798 & 1.679 \\
\% of Variance & 41.742 & 25.687 & 23.990 \\
Cumulative \% & 41.742 & 67.429 & 91.419 \\
\hline
\end{tabular}

\section{DISCUSSION}

The current result agrees with the findings of Andrade et al. (2009), who reported that the total storage root yields of five sweetpotato varieties from Sub-Saharan Africa ranged between 0.5 and 65t/ha. Consistent with the results of this study, Mcharo and Ndolo (2013) and Nedunchezhiyan et al. (2007) reported large differences between sweetpotato clones in terms of root yield due to genetic variation. The range of values for the fresh storage root yield among the genotypes in this study is consistent with earlier studies carried out at different regions across the globe (Kabi et al., 2001; Stathers et al., 2003; Tigabu and Tilahun, 2013; Amare et al., 2015; Mansaray et al., 2015). The yield obtained varied from 1.72 to $13.33 \mathrm{t} / \mathrm{ha}$ in 2015 cropping season and 2.00 to 6.73 in 2016 cropping season, which was not much different from 3.5 to 9t/ha reported by Bidzakin et al., (2014) on various sweetpotato varieties in rural areas. Fresh storage root yields obtained from this investigation performed below their yield potential 
Vol. 06, No. 06; 2021

ISSN: $2456-8643$

(ranging from 18 to $30 \mathrm{t} / \mathrm{ha}$ ) reported by CSIR-Crops Research Institute (MoFA, 2014). The variation in the fresh storage root yield between both cropping season observed in this study and other studies could be attributed to environmental factors and partly be as a result of climatic conditions (Osiru et al., 2009; Mwololo et al., 2012).

The positive correlation established between the fresh storage root yield and Cylas incidence and severity could be attributed to that fact that during storage root formation stage, the storage roots cause cracks in the soil or may the exposed above the soil surface which increases the chance of accessibility to the weevil. Since Cylas weevils are do not dig its way into the soil to dig hole into the soil, it takes advantage of cracks in the soil to penetrate storage root underground (Smit, 1997). In the current study, genotypes such as SautiX442162/5 which produced bigger storage root recorded had higher degrees of infestation. Findings of Kabi et al., (2001) and Stathers et al., (2003) established that there is relationship between root sizes with storage root infestation.

Twelve (12) genotypes; Sauti PC/2, Sauti PC/3, Sauti PC/6, Sauti PC/7, Sauti PC/8, Sauti PC/9, Sauti PC/10, SautiX442162/4, SautiXLigri/1, SautiXLigri/3, SautiXLigri/4, SautiXLigri/5 were also found to be resistant to Cylas puncticollis, and could be incorporated in breeding programs to produce hybrid varieties that are high yielding and resistance to Cylas puncticollis. Ngeve (2001) opined that the selection of accessions should be based on resistance to pest infestation, as root yields and related traits were strongly correlated with weevil damage.

According to Afuape et al. (2011), within the group of genotypes, PCA is a technique to identify which plant traits is the most contributing to the observed variation. Afuape et al. (2011), who reported a cumulative variance of $76.00 \%$ for the first three axes in the evaluation of twenty-one sweetpotato genotypes, found important traits to be the genotypes they worked with. Four main components (PC) were identified, accounting for $67.22 \%$ of the total variation between accessions (Koussao et al., 2014). Placide et al., (2015) also used PCA to study the variability between 54 sweetpotato genotypes and found the cumulative variance of $77.83 \%$ from the first seven major component axes. The results of this study are in agreement with the results of these authors as there was enough variability to support the choice between genotypes.

\section{CONCLUSION}

The study indicated that two genotypes SautiXLigri/4 (13.33t/ha) and SautiX442162/1 (12.70 t/ha) produced higher fresh storage root yield than the national check (Umuspo 3). Twelve (12) genotypes were also found to be resistant to C. puncticollis. The study confirmed that Cylas puncticollis on storage roots was associated with sweetpotato fresh storage root. The study also indicated that the level of Cylas puncticollis severity was associated with the level of damage on roots. The selected genotypes for high yield and resistance to $C$. puncticollis are recommended for multi-locational trails and weevil resistance breeding programs of sweetpotato in Nigeria.

\section{REFERENCES}

Afuape, S.O., Okocha, P. I,, Njoku, D., (2011). Multivariate assessment of the agromorphological variability and yield components among sweet potato (Ipomoea batatas (L.) Lam) landraces. Afr J Pl Sci 5 (2): 123-132. 
Vol. 06, No. 06; 2021

ISSN: $2456-8643$

Amare, B., Abay, F. and Tsehaye, Y. (2015). Evaluation of sweet potato (Ipomea batata I.) Varieties for Total Storage Root Yield in South East Zones of TIgray, Ethiopia. American Journal of Trade and policy 1(2): 74-78.

Andrade, E.K.V., Carvalho de Andrade Junior V., Luiz de Laia, M., Cunha Fernandes, J. S., Oliveira A. J. M., Azevedo. A.M. (2017). Genetic dissimilarity among sweet potato genotypes using morphological and molecular descriptors. Acta Sci. Agron. 39:447-455.

Aniaobong, E.E. and E.E. Bassey, 2008. Constraints and prospects of sweet potato (Ipomoea batatas L.) production in humid environment of southeastern Nigeria. Proceedings of the second african regional conference on sustainable agriculture, (SARCSA'08), Governor's office Annex, Uyo, Nigeria, pp: 68-72.

Anyanga, M. O., Muyinza, H., Talwana, H., Hall, D. R., Farman, D. I., Ssemakula, G. N., Mwanga, R. O. M. and Stevenson, P. C. (2013). Resistance to the weevils Cylas puncticollis and Cylas brunneus Conferred by Sweetpotato Root Surface Compounds. Journal of Agricultural and Food Chemistry 61: 8141-8147.

Bidzakin, J. K., Acheremu, K. and Carey, E. (2014). Needs assessment of sweet potato production in northern Ghana: implications for research and extension efforts. ARPN Journal of Agricultural and Biological Science 9 (9): 315-319.

Burri, B.J. (2011). Evaluating sweet potato as an intervention food to prevent vitamin A deficiency. Compr Rev Food Sci Food Saf. 10:118-130.

Engoru, P., Mugisha, J., Bashaasha, B. (2005). Tuber utilization options among sweet potato producers in eastern Uganda. Afr Crop Sci J. 7:715-719

FAO (2006). Food and Agricultural Organization. Production year book of the United Nations

FAO. 2015. Food and Agriculture Organisation of the United Nations-Crop Production Statistics. Available: http://faostat.fao.org/.

FAOSTAT (2014) Food and Agriculture Organisation of the United Nations: Crop production data. FAOSTAT Division, Rome.

FAOSTAT. 2009. Food and Agriculture Organization of the United Nations Database. Food and Agriculture Organization of the United Nations.

Gibson, R. W. and Aritua, V. 2002. The perspective of sweetpotato chrolotic Stunt virus in sweet potato production in Africa: A review. African Crop Science Journal, 10(4): 281-310.

Kabi, S., Ocenga-Latigo, M. W., Smit, N. E. J. M., Stathers, T. E. and Rees, D. (2001). Influence of Sweetpotato Rooting Characteristics on Infestation and Damage by Cylas spp. African Crop Science Journal 1(9): 165-174. 
Koussao, S., Gracen, V., Asante, I., Danquah, E. Y., Ouedraogo, J. T., Baptiste, T. J., Jerome, B., \& Vianney, T. M (2014). Diversity analysis of sweet potato (Ipomoea batatas [L.] Lam) germplasm from Burkina Faso using morphological and simple sequence repeats markers. African Journal of Biotechnology, 13(6), 729-742.

Lebot, V. 2010. Sweetpotato. In: J. E. Bradshaw (ed.), root and tuber Crops. Handbook of Plant breeding 7:97. Doi 10.1007/978-0-387-92765-7_3, (c) springer Science+business media, llc 2010.

Levett, M. P. (1993). The effects of methods of planting cuttings of sweet potato (Ipomoea batatas (L) Lam) on yield. Tropical Agriculture (Trinidad), 70(2), 110-115.

Mansaray, A., Sundufu, A. J., Moseray, M. T. and Fomba, S. N. (2015). Sweet potato weevil (Cylas puncticollis) Boheman Infestation: Cultivar Differences and the Effects of Mulching. Entomology Journal 9: 7-11.

Masumba E, Kulembeka H, Tollano S, Yongolo M (2005) Participatory evaluation of improved sweetpotato varieties in Eastern Tanzania. Afr Crop Sci J. 12:259-265

Mcharo and Ndolo. 2013. Sweet potato root-yield performance in Kenya 4914 Root-yield performance of pre-release sweet potato genotypes in Kenya. Journal of Applied Biosciences. 65:4914 - 4921: ISSN 1997-5902.

MoFA, (2014). Sweetpotato production guide. Pp 14.

Muyinza, H., Talwana, H. L., Mwanga, R. O. and Stevenson, P. C. (2012). Sweetpotato weevil (Cylas spp.) resistance in African sweetpotato germplasm. International Journal of Pest Management 58: 73-81.

Mwanga R, Odongo B, Niringiye C, Kapinga R, Tumwegamire S, Abidin P, Carey E, Lemaga B, Nsumba J, Zhang D (2007) Sweetpotato selection releases: lessons learnt from Uganda. Afr Crop Sci J. 15: $11-23$

Mwololo, J. K., Mburu, M. W. and Muturi, P. W. (2012). Performance of sweet potato varieties across environments in Kenya. International Journal of Agricultural Research 2(10): 1-11.

National Root Crops Research Institute (2012). Annual Report of the National Root Crops Research Institute, Umudike.

Ndunguru, G., Thomson, M., Waida, R., Rwiza, E. and Westby, A. (1998). Methods for examining the relationship between quality characteristics and economic values of marketed fresh sweet potato. Tropical Agriculture 75: 129-133.

Nedunchezhiyan, M, Susantha K. Jata, Byju G.2 2007. Sweet potato agronomy. Fruit, vegetable and cereal science and Biotechnology Global science book. Reinal center of central tuber crops research institute, bhubaneswwar-751 019, India. 
Vol. 06, No. 06; 2021

ISSN: $2456-8643$

Nedunchezhiyan, M., G. Byju and S.K. Naskar, 2007. Sweet potato (Ipomoea batatas L.) as an intercrop in a coconut plantation: Growth, yield and quality. J. Root Crops, 33: 26-29.

Ngeve, J. M. (2001). Field performance and reaction to weevils of improved and local sweet potato genotypes in Cameroon. In M. O. Akoroda, \& J. M. Ngeve (Eds.), Root Crops in the 21st Century (pp. 290-297). Proceedings of the 7th Triennial Symposium of the International Society for Tropical Root Crops-African Branch, 11-17 October

Osiru, M. O., Olanya, O. M., Adipala, E., Kapinga, R. and Lemaga, B. (2009). Yield stability analysis of Ipomoea batatas L. cultivars in diverse environments. Australian Journal of Crop Science 3(4): 213-220.

Placide, R., H. Shimelis, M. Laing, and D. Gahakwa. 2015. Phenotypic characterisation of sweetpotato genotypes grown in East and Central Africa. S. Afr. J. Plant Soil 32:77-86

Rees, D., Van Oirschot, Q. E. A., Kapinga, R. E., Mtunda, K., Chilosa, D., Mbilinyi, L. B., Rwiza, E. J., Kilima, M., Kiozya, H., Amour, R., Ndondi, T., Chottah, M., Mayona, C. M., Mende, D., Tomlins, K. I., Aked, J. and Carey, E. E. (2003). Extending root shelf-life during marketing by cultivar selection. In: Rees D, Quirien O, Kapinga R, editors. Sweet Potato postharvest assessment. Experiences from East Africa. London: University of Greenwich.

Sebastiani, S.K., Mgonja, A., Urio, F., Ndondi, T. (2007). Agronomic and economic benefits of sweetpotato (Ipomoea batatas) response to application of nitrogen and phosphorus fertilizer in the northern highlands of Tanzania. African Crop Science Conference Proceedings 8: 12071210 .

Smit, N. E. J. M. (1997). Integrated pest management for sweet potato in Eastern Africa. Ph.D. Thesis, Agricultural University, Wageningen. $151 \mathrm{pp}$

Smit, N. E. J. M., Downham, M. C. A., Laboke, P. O., Hall, D. R. and Odongo, B. (2001). Masstrapping male Cylas spp with sex pheromones; a potential IPM component in sweetpotato production in Uganda. Crop Protection 20: 643-651.

Stathers T.E., Rees, D., Kabi, S., Mbilinyi, L., Smit, N., Kiozya, H., Jeremiah, S., Nyango, A., Jeffries, D. (2003). Sweetpotato infestation by Cylas spp. in East Africa: I. Cultivar differences in field infestation and the role of plant factors. Int J Pest Manage. 49: 131-140.

Stathers, J. E., Rees, D. and Jeffries, D. (1999). Investigating the potential of cultivar differences in susceptibility to sweetpotato weevil as a means of control. Final Report Department for International Development (DFID) crop post-harvest program, Natural Resource Institute.

Tigabu, B., Tilahun, B. (2013). Performance Evaluation of Improved Sweet Potato (Ipomoea batatas L.) Varieties at Gedeo Zone, Southern Ethiopia. International Journal of Science and Research 4(9): 116-119. 